Джоші О. І., к.Т.н., доцент

(Національний університет водного господарства та природокористування, м. Рівне)

\title{
АНАЛІЗ ДЕМОГРАФІЧНИХ ПОКАЗНИКІВ РІВНЕНСЬКОЇ ОБЛАСТІ
}

У роботі наведено результати статистичного аналізу та аналізу на основі методології часових рядів (АКФ, ЧАКФ, тест Дікі-Фулера) таких демографічних показників, як кількість народжених та померлих, чисельність наявного та постійного населення у Рівненській області за період 1950-2018 рр. У середовищі економетричного пакету EViews реалізовано перевірку часових рядів відповідних демографічних показників на стаціонарність i запропоновано рекомендації щодо побудови їх математичних моделей.

Ключові слова: аналіз; демографічні показники; часовий ряд; тест Дікі-Фулера.

Постановка проблеми. Демографічна ситуація відіграє важливу роль у соціально-економічному розвитку, як держави в цілому, так і областей країни зокрема. Надзвичайно швидка трансформація політичної, економічної, соціальної сфер життя створили певні перешкоди в адаптації більшості населення України до нових умов.

Потреба у демографічній інформації завжди $є$ актуальною. Без достовірної демографічної статистики та ї̈ аналізу не можна визначити, скільки потрібно побудувати нового житла, шкіл та дитячих садочків, поліклінік, лікарень, яким буде навантаження на міський або приміський пасажирський транспорт, чи достатньо продовольчих та непродовольчих ресурсів для задоволення потреб населення, наскільки великими є розміри міграційного приросту або відтоку населення тощо.

Аналіз останніх досліджень та публікацій. Демографічним проблемам та їх впливу на економічний розвиток України в цілому, i iï адміністративно-територіальних одиниць, присвячені праці таких науковців, як Д.П.Богиня, О.М.Грішнова, Г.Дмитренко, М.ІІДолішній, Т.А. Заяць, І.С.Кравченко, Ю.М.Краснов, О. Є. Кузьмін, В.І.Куценко, Е. М. Лібанова, В. В. Онікієнко, В. С. Стешенко, С. І. Пирожков, С. Цапка та інші.

При дослідженні демографічних процесів вітчизняні науковці надають перевагу застосуванню таких методів, як: екстраполяційний, пересування вікових груп (або метод компонент) та аналітичний, основою якого є кореляційно-регресійний аналіз. 
В той же час практично відсутні дослідження цих процесів, в яких застосовуються методи аналізу і прогнозування на основі методології часових рядів. Основні праці 3 методології аналізу часових рядів належать Т. Андерсону, В. Н. Афанасьєву, В. В. Іванову, Ю. Л. Лукашину, М. Четиркіну, Дж. Боксу (G. Box), Д. Бриллінджеру (D. Brillinger), Т. Боллерслеву (T. Bollerslev), Д. Дікі (D. Dickey), В. Фуллеру (W. Fuller), М. Хатанака (M. Hatanaka), В. Ендерсу (W. Enders) та іншим.

Мета і завдання дослідження. Метою дослідження $є$ аналіз демографічних показників Рівненської області 3 врахуванням природного та міграційного процесів для визначення кількісних змін населення області, а також розробка рекомендацій щодо побудови їх математичних моделей. 3 метою досягнення поставленої мети було передбачено виконання наступних завдань:

1) відбір демографічних показників Рівненській області;

2) статистичний аналіз досліджуваних демографічних показників за період 1990-2018 роки;

3) аналіз часових рядів демографічних показників за період 1950-2018 роки;

4) ідентифікація моделей часових рядів.

\section{Виклад основного матеріалу}

Для аналізу демографічних показників Рівненської області, виходячи з наявної статистичної інформації [1; 2], було обрано наступні часові ряди за 1950-2018 рр.: кількість народжених, кількість померлих, кількість наявного населення та кількість постійного населення в міських поселеннях і в сільській місцевості відповідно.

За результатами статистичного аналізу демографічних показників Рівненської області було встановлено, що у 2018 році кількість народжених склала 13380 осіб, що на 5139 менше, ніж у 1990 році (табл. 1). 3 них 5460 осіб народилося в міських поселеннях (зменшилося за цей період на 3924 осіб) та 7920 осіб - в сільській місцевості (зменшення за аналогічний період склало 1215 осіб). Кількість померлих в Рівненській області у 2018 року склала 14528 осіб (в порівнянні з 1990 роком значення даного показника збільшилося на 2091 осіб). Щодо типу місцевості, то в міських поселеннях кількість померлих в порівнянні з 1990 роком зросла на 1666 осіб і склала 5653 осіб, а в сільській місцевості за цей самий період збільшення даного показника склало 425 осіб. 
Таблиця 1

Динаміка демографічних показників міського та сільського населення Рівненської області за 1990-2018 рр.

\begin{tabular}{|c|c|c|c|c|c|c|c|c|c|c|}
\hline \multirow{3}{*}{ Рік } & \multicolumn{5}{|c|}{ Кількість народжених } & \multicolumn{5}{|c|}{ Кількість померлих } \\
\hline & \multirow[t]{2}{*}{ Bcboro } & \multicolumn{2}{|c|}{$\begin{array}{c}\text { міські } \\
\text { поселення }\end{array}$} & \multicolumn{2}{|c|}{$\begin{array}{c}\text { сільська } \\
\text { місцевість }\end{array}$} & \multirow[t]{2}{*}{ Всього } & \multicolumn{2}{|c|}{$\begin{array}{c}\text { міські } \\
\text { поселення }\end{array}$} & \multicolumn{2}{|c|}{$\begin{array}{c}\text { сільська } \\
\text { місцевість }\end{array}$} \\
\hline & & ociб & $\%$ & ocí & $\%$ & & осіб & $\%$ & осіб & $\%$ \\
\hline 1990 & 18519 & 9384 & 50,7 & 9135 & 49,3 & 12437 & 3987 & 32,1 & 8450 & 67,9 \\
\hline 1995 & 16469 & 7151 & 43,4 & 9318 & 56,6 & 15282 & 5421 & 35,5 & 9861 & 64,5 \\
\hline 2000 & 13898 & 5316 & 38,3 & 8582 & 61,7 & 15499 & 5706 & 36,8 & 9793 & 63,2 \\
\hline 2005 & 14483 & 6064 & 41,9 & 8419 & 58,1 & 16421 & 5903 & 35,9 & 10518 & 64,1 \\
\hline 2010 & 17074 & 7103 & 41,6 & 9971 & 58,4 & 14997 & 5542 & 37,0 & 9455 & 63,0 \\
\hline 2015 & 16137 & 6655 & 41,2 & 9482 & 58,8 & 14695 & 5564 & 37,9 & 9131 & 62,1 \\
\hline 2018 & 13380 & 5460 & 40,8 & 7920 & 59,2 & 14528 & 5653 & 38,9 & 8875 & 61,1 \\
\hline $\begin{array}{c}\Delta \\
2018 / \\
1990\end{array}$ & -5139 & -3924 & \multirow{3}{*}{ - } & -1215 & \multirow{3}{*}{+} & 2091 & 1666 & \multirow{3}{*}{+} & 425 & \multirow{3}{*}{-} \\
\hline $\begin{array}{c}T_{3 p} \\
2018 / \\
1990\end{array}$ & 72,3 & 58,2 & & 86,7 & & 116,8 & 141,8 & & 105,0 & \\
\hline $\begin{array}{c}T_{\mathrm{np}} \\
2018 / \\
1990\end{array}$ & $-27,7$ & $-41,8$ & & $-13,3$ & & 16,8 & 41,8 & & 5,0 & \\
\hline \multirow{3}{*}{ Рік } & \multicolumn{5}{|c|}{ Кількість наявного населення } & \multicolumn{5}{|c|}{ Кількість постійного населення } \\
\hline & \multirow{2}{*}{ Bcboro } & \multicolumn{2}{|c|}{$\begin{array}{c}\text { міські } \\
\text { поселення }\end{array}$} & \multicolumn{2}{|c|}{$\begin{array}{c}\text { сільська } \\
\text { місцевість }\end{array}$} & \multirow{2}{*}{ Bcboro } & \multicolumn{2}{|c|}{\begin{tabular}{c|} 
міські \\
поселення \\
\end{tabular}} & \multicolumn{2}{|c|}{$\begin{array}{c}\text { сільська } \\
\text { місцевість }\end{array}$} \\
\hline & & $\begin{array}{l}\text { тис. } \\
\text { осіб }\end{array}$ & $\%$ & $\begin{array}{l}\text { тис. } \\
\text { осіб }\end{array}$ & $\%$ & & $\begin{array}{l}\text { тис. } \\
\text { осіб }\end{array}$ & $\%$ & $\begin{array}{l}\text { тис. } \\
\text { осіб }\end{array}$ & $\%$ \\
\hline 1990 & 1173,3 & 540,8 & 46,1 & 632,5 & 53,9 & 1167,7 & 536,8 & 46,0 & 630,9 & 54,0 \\
\hline 1995 & 1194,5 & 568,1 & 47,6 & 626,4 & 52,4 & 1187,2 & 560,2 & 47,2 & 627,0 & 52,8 \\
\hline 2000 & 1183,3 & 561,4 & 47,4 & 621,9 & 52,6 & 1179,1 & 552,4 & 46,8 & 626,7 & 53,2 \\
\hline 2005 & 1160,7 & 546,3 & 47,1 & 614,4 & 52,9 & 1159,7 & 541,0 & 46,6 & 618,7 & 53,4 \\
\hline 2010 & 1151,6 & 550,2 & 47,8 & 601,4 & 52,2 & 1150,6 & 545,0 & 47,4 & 605,6 & 52,6 \\
\hline 2015 & 1161,2 & 554,2 & 47,7 & 607,0 & 52,3 & 1160,1 & 548,9 & 47,3 & 611,2 & 52,7 \\
\hline 2018 & 1160,6 & 550,9 & 47,5 & 609,7 & 52,5 & 1159,6 & 545,6 & 47,1 & 614,0 & 52,9 \\
\hline $\begin{array}{c}\Delta \\
2018 / \\
1990\end{array}$ & $-12,7$ & 10,1 & \multirow{3}{*}{$x_{1}$} & $-22,8$ & \multirow{3}{*}{ - } & $-8,1$ & 8,8 & \multirow{3}{*}{+} & $-16,9$ & \multirow{3}{*}{ - } \\
\hline $\begin{array}{c}T_{3 p} \\
2018 / \\
1990\end{array}$ & 98,9 & 101,9 & & 96,4 & & 99,3 & 101,6 & & 97,3 & \\
\hline $\begin{array}{c}T_{\text {np }} \\
2018 / \\
1990 \\
\end{array}$ & $-1,1$ & 1,9 & & $-3,6$ & & $-0,7$ & 1,6 & & $-2,7$ & \\
\hline
\end{tabular}

Співвідношення народжених міського та сільського населення Рівненької області за останні роки змінилося з приблизно 51\% до 
41\% та з 49\% до 59\% відповідно. Що стосується показника кількості померлих, то зміна його співвідношення $є$ наступною: для міського населення Рівненької області вона склала з приблизно $32 \%$ до $39 \%$ та для сільського населення - 3 68\% до $61 \%$.

Що стосується таких демографічних показників як кількість постійного та наявного населення, то результати аналізу їх динаміки в Рівненській області $€$ наступними. 31990 року до 2018 року відбулося зменшення кількості постійного населення на 12,7 тис. осіб і склало у 2018 році 1160,6 тис. осіб. При цьому у міських поселеннях відбулося збільшення даного показника на 10,1 тис. осіб, а у сільській місцевості навпаки зменшення, яке склало 22,8 тис. осіб. Для показника кількість постійного населення його значення у 2018 році склало 1159,6 тис. осіб, тобто в порівнянні з 1990 роком відповідає зменшенню на 8,1 тис. осіб: в міських поселеннях кількість постійного населення з 1990 року до 2018 року збільшилася на 8,8 тис. осіб і на 2018 рік склала 545,6 тис. осіб, а в сільській місцевості, так само як і значення показника кількість наявного населення, навпаки зменшилося за аналогічний період на 16,9 тис. осіб і склало 614,0 тис. осіб. Співвідношення міського та сільського населення Рівненької області за останні роки суттєво не змінюється і складає близько $47 \%$ та 53\% відповідно.

Отже, в демографічних процесах Рівненської області, їх динаміці, відіграє роль як природній (відтворення), так і механічний (міграція) рух населення. За останні роки в міських поселеннях переважає зменшення народжуваності; в сільській місцевості переважає зменшення наявного та постійного населення. Постає питання щодо побудови адекватних математичних моделей, які б дозволили отримати якісні прогнозні значення досліджуваних демографічних показників. 3 цією метою спочатку здійснюється аналіз часових рядів відповідних показників. Часові ряди відповідних показників за означений період наведено на рис. 1.

3 метою ідентифікації часових рядів для наведених даних було використано наступні підходи [3; 4; 5]:

- візуальний аналіз графіку часового ряду;

- статистичний аналіз демографічних показників;

- аналіз графіку автокореляційної функції;

- узагальнений тест Дікі-Фулера (Dickey-Fuller).

На всіх графіках можна помітити, що починаючи 3 60-х років відбуваються певні демографічні зрушення: зменшується кількість народжених (переважно внаслідок суттєвого зменшення народжуваності в сільській місцевості); збільшується кількість 
померлих, як в міських поселеннях, так і в сільській місцевості; збільшується кількість наявного та постійного населення (переважно внаслідок його збільшення в міських поселеннях).

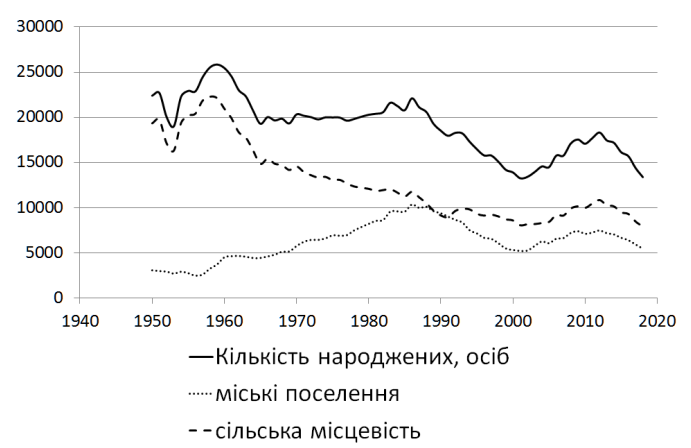

a)

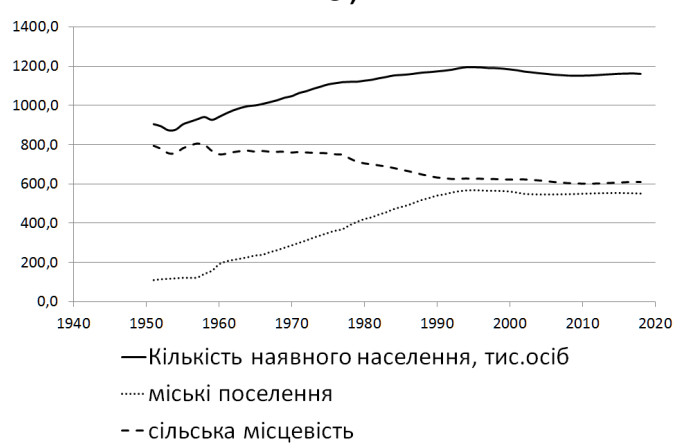

B)

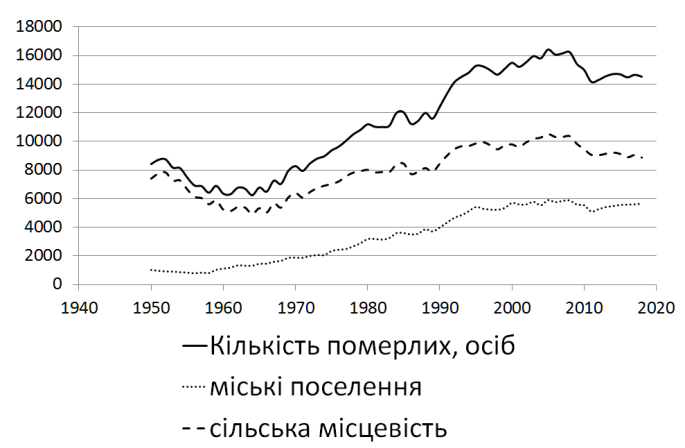

б)

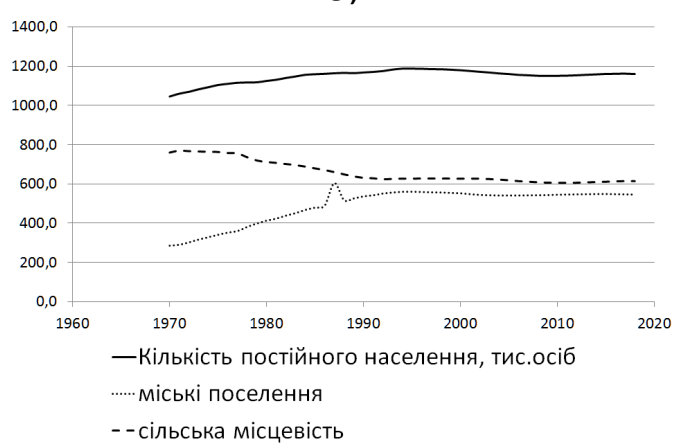

г)

Рис. 1. Часові ряди: а) кількості народжених 1950-2018 рр.;

б) кількості померлих 1950-2018рр.; в) кількості наявного населення 1950-2018 рр.; г) кількості постійного населення 1970-2018 рр.

в Рівненській області, в т.ч. міського та сільського населення

Візуальний аналіз графіків часових рядів (рис. 1) показує, що досліджувані часові ряди ймовірно $€$ нестаціонарними та можуть бути ідентифіковані як часові ряди з детермінованим трендом (trend stationary time series або TS-ряди). Такі ряди ще називають стаціонарними відносно детермінованого тренду (лінійного або нелінійного).

У середовищі програмного пакету EViews для відповідних часових рядів були побудовані автокореляційні (АКФ) та частково автокореляційні (ЧАКФ) функції (рис. 2), аналіз яких дозволяє визначити вид порядку моделі. При цьому використовуються наступні практичні критерії:

- якщо АКФ експоненційно затухає, а ЧАКФ характеризується тим, що має перший значущий елемент (при лаговій змінній 1), то в цьому випадку для математичного опису процесу доцільно використовувати модель авторегресії першого порядку (AR(1)) 


$$
Y_{t}=a_{0}+\alpha Y_{t-1}+\varepsilon_{t} ;
$$

- якщо АКФ має форму затухаючої синусоподібної хвилі або експоненційно затухає, а ЧАКФ має перший та другий значущі елементи (при лагових змінних 1 та 2), то для математичного опису такого процесу доцільно використовувати модель авторегресії другого порядку $(\mathrm{AR}(2))$

$$
Y_{t}=a_{0}+\alpha Y_{t-1}+\alpha Y_{t-2}+\varepsilon_{t} .
$$

Отже, для математичного моделювання часових рядів кількості народжених, кількості померлих та кількості наявного населення доцільно застосовувати модель $\mathrm{AR}(1)$, а для математичного моделювання часового ряду кількості постійного населення в Рівненській області - модель $A R(1)$ або $A R(2)$.

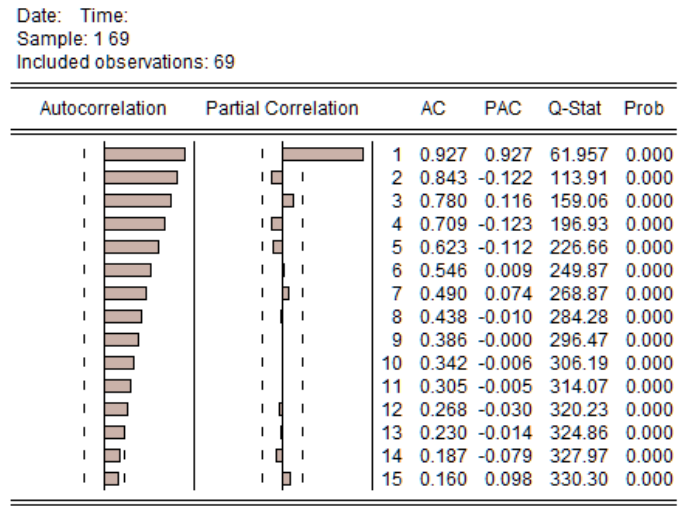

a)

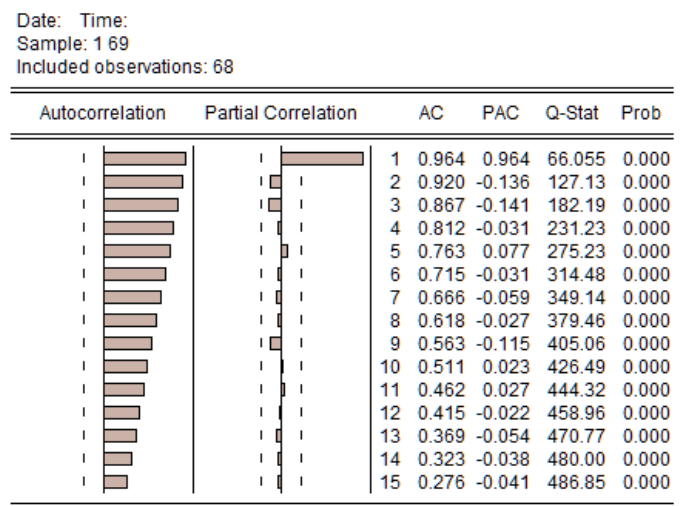

B)

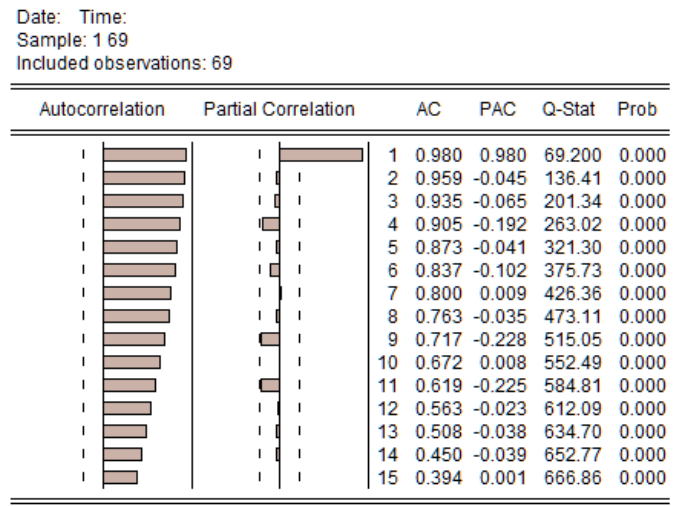

б)

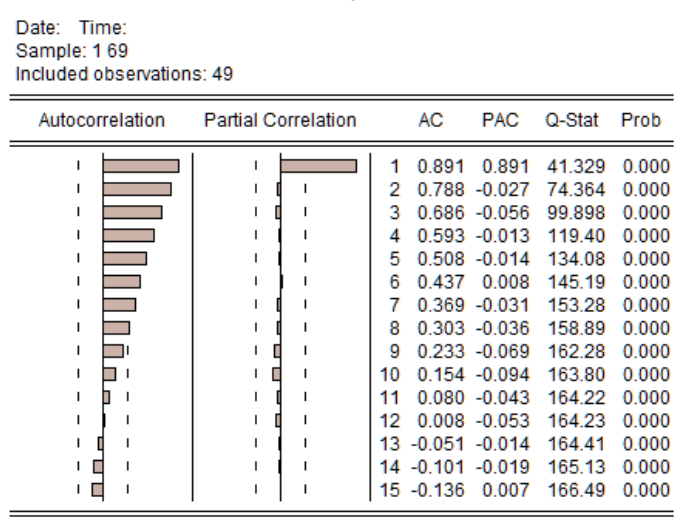

г)

Рис. 2. Графіки автокореляційних та частково автокореляційних функцій часових рядів: а) кількості народжених; б) кількості померлих; в) кількості наявного населення; г) кількості постійного населення в Рівненській області

Перевірка на стаціонарність часових рядів була здійснена за допомогою тесту Дікі-Фулера у середовищі програмного пакету EViews (pиc. 3). 
Null Hypothesis: $Y 1$ has a unit root

Lag Length: 0 (Automatic - based on AIC, maxlag=0)

\begin{tabular}{lccc}
\hline \hline & & t-Statistic & Prob. $^{*}$ \\
\hline \hline Augmented Dickey-Fuller test statistic & -0.712581 & 0.8362 \\
\hline Test critical values: $\quad$ 1\% level & -3.530030 & \\
& $5 \%$ level & -2.904848 & \\
& $10 \%$ level & -2.589907 & \\
& & &
\end{tabular}

${ }^{*}$ MacKinnon (1996) one-sided p-values.

Augmented Dickey-Fuller Test Equation

Dependent Variable: D(Y1)

Method: Least Squares

Date: Time:

Sample (adjusted): 269

Included observations: 68 after adjustments

\begin{tabular}{lrlcr}
\hline \hline \multicolumn{1}{c}{ Variable } & Coefficient & Std. Error & t-Statistic & Prob. \\
\hline \hline \multicolumn{1}{c}{ Y1(-1) } & -0.025233 & 0.035410 & -0.712581 & 0.4786 \\
& 350.0702 & 686.1876 & 0.510167 & 0.6116 \\
\hline \hline R-squared & 0.007635 & Mean dependent var & -132.6912 \\
Adjusted R-squared & -0.007401 & S.D. dependent var & 895.1463 \\
S.E. of regression & 898.4527 & Akaike info criterion & 16.46820 \\
Sum squared resid & 53276344 & Schwar criterion & 16.53348 \\
Log likelihood & -557.9187 & Hannan-Quinn criter. & 16.49406 \\
F-statistic & 0.507772 & Durbin-Watson stat & 1.527740 \\
Prob(F-statistic) & 0.478617 & & \\
\hline \hline
\end{tabular}

a)

Null Hypothesis: $Y 3$ has a unit root

Exogenous: Constant

Lag Length: 0 (Automatic - based on AIC, maxlag $=0$ )

\begin{tabular}{lccc}
\hline \hline & & t-Statistic & Prob. \\
\hline \hline \multicolumn{2}{l}{ Augmented Dickey-Fuller test statistic } & -3.198772 & 0.0244 \\
\hline Test critical values: & 1\% level & -3.531592 & \\
& $5 \%$ level & -2.905519 & \\
& 10\% level & -2.590262 & \\
\hline \hline
\end{tabular}

*MacKinnon (1996) one-sided p-values.

Augmented Dickey-Fuller Test Equation

Dependent Variable: $\mathrm{D}(\mathrm{Y} 3)$

Method: Least Squares

Date: Time:

Sample (adjusted): 268

Included observations: 67 after adjustments

\begin{tabular}{lrlll}
\hline \hline \multicolumn{1}{c}{ Variable } & Coefficient & Std. Error & t-Statistic & Prob. \\
\hline \hline \multicolumn{1}{c}{ Y3(-1) } & -0.028913 & 0.009039 & -3.198772 & 0.0021 \\
C & 35.47219 & 9.932234 & 3.571421 & 0.0007 \\
\hline \hline R-squared & 0.136008 & Mean dependent var & 3.826075 \\
Adjusted R-squared & 0.122715 & S.D. dependent var & 7.686987 \\
S.E. of regression & 7.199899 & Akaike info criterion & 6.815407 \\
Sum squared resid & 3369.505 & Schwarz criterion & 6.881219 \\
Log likelihood & -226.3161 & Hannan-Quinn criter. & 6.841449 \\
F-statistic & 10.23214 & Durbin-Watson stat & 0.991363 \\
Prob(F-statistic) & 0.002134 & & \\
\hline \hline
\end{tabular}

B)
Null Hypothesis: Y2 has a unit root

Exogenous: Constant

Lag Length: 0 (Automatic - based on AIC, maxlag=0)

\begin{tabular}{lccc}
\hline \hline & & t-Statistic & Prob. $^{*}$ \\
\hline \hline \multicolumn{2}{l}{ Augmented Dickey-Fuller test statistic } & -0.476724 & 0.8887 \\
\hline \multicolumn{2}{l}{ Test critical values: $\quad$ 1\% level } & -3.530030 & \\
& $5 \%$ level & -2.904848 & \\
& $10 \%$ level & -2.589907 & \\
\hline \hline
\end{tabular}

*MacKinnon (1996) one-sided p-values.

Augmented Dickey-Fuller Test Equation

Dependent Variable: $\mathrm{D}(\mathrm{Y} 2)$

Method: Leas
Date: Time:

Date: Time:

Included observations: 68 after adjustments

\begin{tabular}{lrlcc}
\hline \hline \multicolumn{1}{c}{ Variable } & Coefficient & Std. Error & t-Statistic & Prob. \\
\hline \hline \multicolumn{1}{c}{ Y2(-1) } & -0.007459 & 0.015647 & -0.476724 & 0.6351 \\
C & 174.4152 & 185.4175 & 0.940662 & 0.3503 \\
\hline \hline R-squared & 0.003432 & Mean dependent var & 89.77941 \\
Adjusted R-squared & -0.011668 & S.D. dependent var & 438.4864 \\
S.E. of regression & 441.0371 & Akaike info criterion & 15.04511 \\
Sum squared resid & 12837903 & Schwarz criterion & 15.11039 \\
Log likelihood & -509.5336 & Hannan-Quinn criter. & 15.07097 \\
F-statistic & 0.227266 & Durbin-Watson stat & 1.826524 \\
Prob(F-statistic) & 0.635133 & & & \\
\hline \hline
\end{tabular}

б)

Null Hypothesis: $\mathrm{Y} 4$ has a unit root

Exogenous: Constant

Lag Length: 0 (Automatic - based on AIC, maxlag=0)

\begin{tabular}{lccc}
\hline \hline & & & \\
& & t-Statistic & Prob. \\
\hline \hline \multicolumn{2}{l}{ Augmented Dickey-Fuller test statistic } & -7.878404 & 0.0000 \\
\hline Test critical values: & 1\% level & -3.574446 & \\
& $5 \%$ level & -2.923780 & \\
& $10 \%$ level & -2.599925 & \\
\hline \hline
\end{tabular}

*MacKinnon (1996) one-sided p-values.

Augmented Dickey-Fuller Test Equation

Dependent Variable: D(Y4)

Method Least Squares

Date: Time:

Sample (adjusted): 249

Included observations: 48 after adjustments

\begin{tabular}{lrlll}
\hline \hline \multicolumn{1}{c}{ Variable } & Coefficient & Std. Error & t-Statistic & Prob. \\
\hline \multicolumn{1}{c}{ Y4(-1) } & -0.106507 & 0.013519 & -7.878404 & 0.0000 \\
\multicolumn{1}{c}{ C } & 124.6585 & 15.52764 & 8.028168 & 0.0000 \\
\hline \hline R-squared & 0.574347 & Mean dependent var & 2.378896 \\
Adjusted R-squared & 0.565094 & S.D. dependent var & 4.819947 \\
S.E. of regression & 3.178631 & Akaike info criterion & 5.191552 \\
Sum squared resid & 464.7699 & Schwarz criterion & 5.269519 \\
Log likelihood & -122.5972 & Hannan-Quinn criter. & 5.221016 \\
F-statistic & 62.06925 & Durbin-Watson stat & 0.557898 \\
Prob(F-statistic) & 0.000000 & & & \\
\hline
\end{tabular}

г)

Рис. 3. Результати тесту Дікі-Фулера для часових рядів: а) кількості народжених; б) кількості померлих; в) кількості наявного населення; г) кількості постійного населення в Рівненській області

Даний тест дозволяє здійснити перевірку часового ряду на стаціонарність залежно від необхідності включення в рівняння, що тестується, вільного члена (Intercept) - ненульового значення перетину

$$
\Delta Y_{t}=b_{0}+b Y_{t-1}+\varepsilon_{t} .
$$

тренду та вільного члена (Trend and intercept)

$$
\Delta Y_{t}=b_{0}+b_{1} t+b Y_{t-1}+\varepsilon_{t},
$$


або невключення нічого (None)

$$
\Delta Y_{t}=b Y_{t-1}+\varepsilon_{t} .
$$

Крім того, під час перевірки можна задати кількість лагів (Lag length). Цю кількість може бути обрано автоматично (Automatic selection), за умови зазначення максимального значення, або задано вручну (User specified). У випадку автоматичної оптимізації кількості лагів використовуються інформаційні критерії Акаіке (Akaike), Шварца (Schwartz) та Хеннана-Квіна (Hannan-Quinn).

Результатом тесту Дікі-Фулера є отримання розрахункового значення та критичних значень $\mathrm{t}-$ статистики МакКінона при 1\%, 5\% та 10\% рівнях значущості, а також p-value (ймовірності). У випадку, якщо виконується умова $p$-value < $10 \%$ роблять висновок про те, що часовий ряд є стаціонарним і навпаки. В залежності від параметрів тесту Дікі-Фулера були отримані наступні значення p-value (рис. 4).

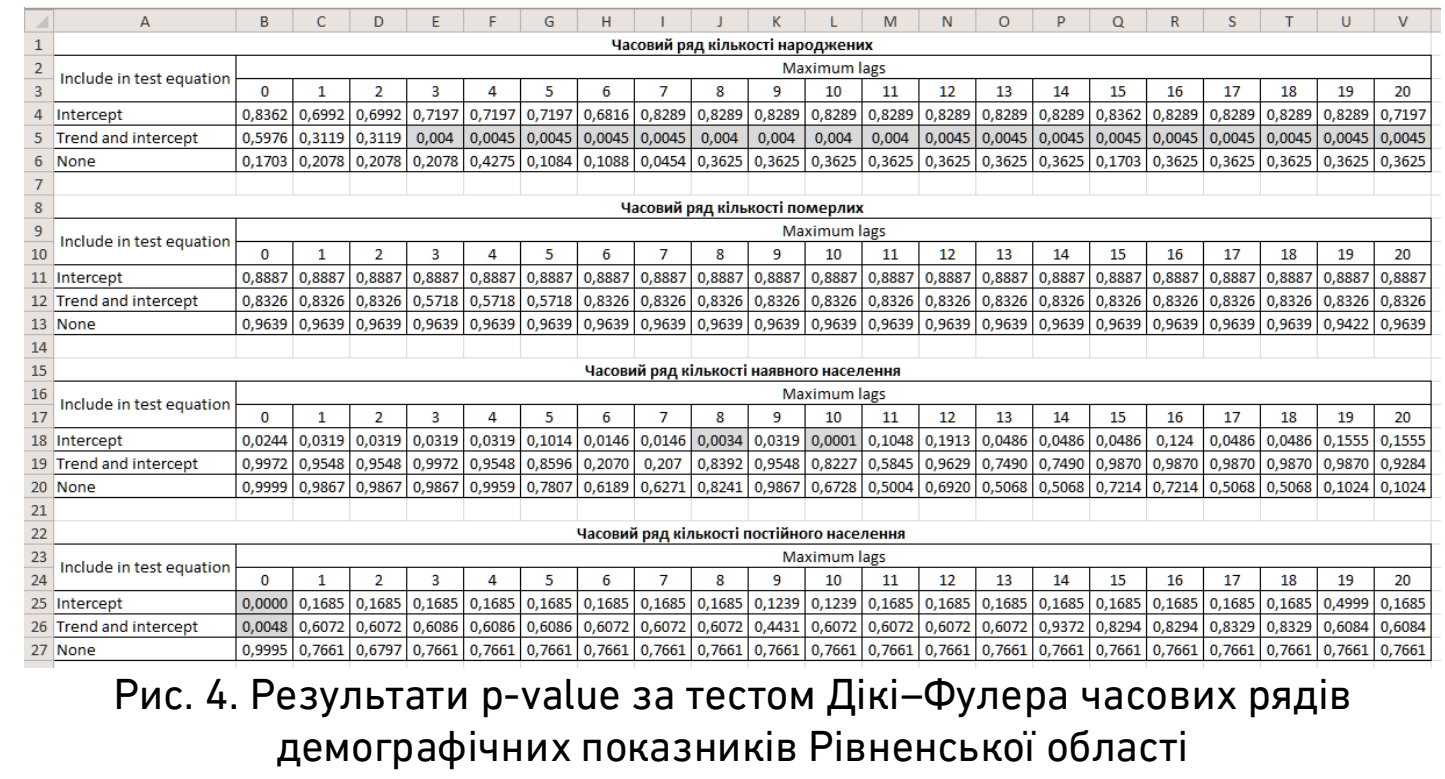

Отже, за результатами проведеного дослідження було виявлено наступне:

- часовий ряд кількості народжених є стаціонарним у випадку включення в рівняння тренду та вільного члена, за умови максимального значення кількості лагів 3 і більше;

- часовий ряд кількості померлих $є$ нестаціонарним;

- часовий ряд кількості наявного населення $є$ стаціонарним у випадку включення в рівняння вільного члена (ненульового значення перетину), за умови максимального значення кількості лагів 8 або 10;

- часовий ряд кількості постійного населення є стаціонарним у 
випадку включення в рівняння вільного члена (ненульового значення перетину) або тренду та вільного члена, за умови максимального значення кількості лагів 0.

Оскільки часовий ряд кількості померлих є нестаціонарним, тест Дікі-Фулера було застосовано до його перших різниць (1st difference). В результаті було отримано наступні значення pvalue (рис. 5).

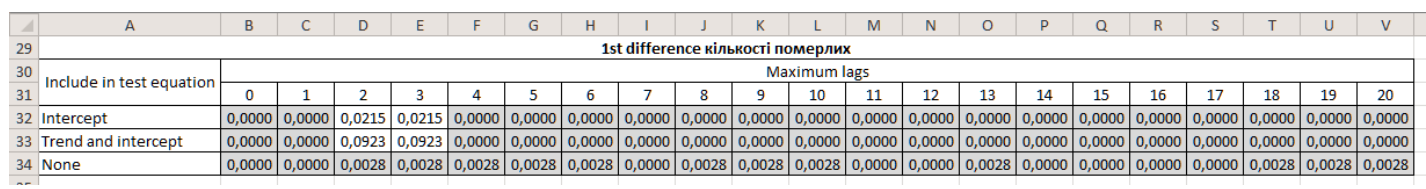

Рис. 5. Результати p-value за тестом Дікі-Фулера ряду перших різниць демографічного показника кількості померлих

Таким чином, за отриманими результатами було встановлено, що ряд перших різниць демографічного показника кількості померлих є стаціонарним у випадках включення в рівняння вільного члена (ненульового значення перетину), або тренду та вільного члена, або невключення нічого за умови, що максимальне значення кількості лагів не буде дорівнювати 2 та 3 для перших двох випадків рівнянь.

\section{Висновки}

1. Основні демографічні показники Рівненської області свідчать про існування демографічної кризи. За останні роки спостерігається зменшення народжуваності, інтенсифікація смертності, зменшення наявного та постійного населення в сільській місцевості.

2. За результатами аналізу АКФ та ЧАКФ часових рядів демографічних показників Рівненської області було встановлено, що для їх моделювання доцільно використовувати моделі авторегресії першого або другого порядку.

Перевірка часових рядів на стаціонарність за тестом ДікіФулера показала, що за певних умов (в залежності від виду рівняння та кількості лагів) деякі часові ряди демографічних показників можна розглядати як стаціонарні. У випадку, якщо часовий ряд $\epsilon$ нестаціонарним, то математичну модель будують не безпосередньо для часового ряду, а для ряду різниць.

1. Сайт Державної служби статистики України. URL: www.ukrstat.gov.ua (дата звернення: 24.02.2020). 2. Статистичні щорічники Рівненської області за 19502007 рр. 3. Лук'яненко І. Г., Городніченко Ю. О. Сучасні економетричні методи у фінансах : навч. посіб. Київ : Літера ЛТД, 2002. 352 с. 4. Бідюк П. І., Романенко В. Д., Тимощук О. Л. Аналіз часових рядів : навч. посіб. Київ : Політехніка, 2010. 317 с. 5. Ханк Д. Э., Уичерн Д. У., Райтс А. Дж. Бизнес-прогнозирование, 7-е изд.: / пер. с англ. Марченко В. В. и др. М. : Издательский дом «Вильямс», 2003. 656 с. 


\section{REFERENCES:}

1. Sait Derzhavnoi sluzhby statystyky Ukrainy. URL: www.ukrstat.gov.ua (data zvernennia: 24.02.2020). 2. Statystychni shchorichnyky Rivnenskoi oblasti za 19502007 rr. 3. Lukianenko I. H., Horodnichenko Yu. O. Suchasni ekonometrychni metody u finansakh : navch. posib. Kyiv : Litera LTD, 2002. 352 s. 4. Bidiuk P. I., Romanenko V. D., Tymoshchuk O. L. Analiz chasovykh riadiv : navch. posib. Kyiv : Politekhnika, 2010. 317 s. 5. Hank D. E., Uichern D. U., Raits A. Dzh. Biznes-prognozirovanie, 7-e izd.: / per. s angl. Marchenko V. V. i dr. M. : Izdatelskii dom «Viliams», 2003. 656 s.

Dzhoshi O. I., Candidate of Engineering (Ph.D.), Associate Professor (National University of Water and Environmental Engineering, Rivne)

\section{ANALYSIS OF THE RIVNE REGION DEMOGRAPHIC INDICATORS}

In this article, results of statistical analysis and analysis based on the methodology of the time series of some demographic indicators are presented. The following indicators are selected as the studied indicators: the number of births and deaths, as well as the number of the obvious and permanent population in the Rivne region for the period 1950-2018. The tasks of the study included the following stages: 1) selection of demographic indicators; 2) statistical analysis of the studied demographic indicators for the period 1990-2018; 3) analysis of time series of demographic indicators for the period 1950-2018; 4) identification of time series models. The main demographic indicators of the Rivne region indicate the existence of a demographic crisis. In recent years, there has been a decrease in the birth rate, an increase in mortality, a decrease in the current and resident population in rural areas. In order to identify time series for the selected data, the following approaches were used: visual analysis of the time series graph; statistical analysis of demographic indicators; analysis of the autocorrelation function graph; generalized Dickey-Fuller test. The implementation of these approaches was carried out in the econometric package EViews. According to the analysis of ACF and PACF time series of demographic indicators of the Rivne region, it was found that for their modeling it is advisable to use first or second order autoregressive models. Checking the time series for stationarity using the Dickey-Fuller test showed that under certain conditions (depending on the type of equation and the number of lags) some time series of demographic indicators can be considered as stationary. If the time series is non-stationary, then the mathematical model is built not directly for the time series, but for a series of differences.

Keywords: analysis; demographic indicators; time series; Dickey-Fuller test. 


\section{АНАЛИЗ ДЕМОГРАФИЧЕСКИХ ПОКАЗАТЕЛЕЙ РОВЕНСКОЙ ОБЛАСТИ}

В работе представлены результаты статистического анализа и анализа на основе методологии временных рядов некоторых демографических показателей. В качестве исследуемых показателей отобраны следующие: количество родившихся и умерших, а также численность наявного и постоянного населения в Ровенской области за период 1950-2018 гг. Задания исследования предусматривали такие этапы: 1) отбор демографических показателей; 2) статистический анализ исследуемых демографических показателей за период 1990-2018 гг.; 3) анализ временных рядов демографических показателей за период 1950-2018 гг.; 4) идентификация моделей временных рядов. Основные демографические показатели Ровенской области свидетельствуют о существовании демографического кризиса. За последние годы наблюдается уменьшение рождаемости, интенсификация смертности, уменьшение наличного и постоянного населения в сельской местности. С целью идентификации временных рядов для отобранных данных были использованы следующие подходы: визуальный анализ графика временного ряда; статистический анализ демографических показателей; анализ графика автокорреляционной функции; обобщенный тест ДикиФулера. Реализация перечисленных подходов была осуществлена в среде эконометрического пакета EViews. По результатам анализа АКФ и ЧАКФ временных рядов демографических показателей Ровенской области было установлено, что для их моделирования целесообразно использовать модели авторегрессии первого или второго порядка. Проверка временных рядов на стационарность с помощью теста ДикиФулера показала, что при определенных условиях (в зависимости от вида уравнения и количества лагов) некоторые временные ряды демографических показателей можно рассматривать как стационарные. В случае если временной ряд является нестационарным, то математическую модель строят не непосредственно для временного ряда, а для ряда разниц.

Ключевые слова: анализ; демографические показатели; временной ряд; тест Дики-Фулера. 